\title{
Implementasi Model Pembelajaran Sentra pada TK Labschool STAI Bani Saleh Bekasi
}

\author{
Sri Watini ${ }^{凶}$ \\ Pendidikan Guru Pendidikan Anak Usia Dini, STKIP Panca Sakti Bekasi \\ DOI: 10.31004/obsesi.v4i1.190
}

\begin{abstract}
Abstrak
Penelitian ini bertujuan untuk mendiskripsikan Implementasi Model Pembelajaran Sentra yang dilaksanakan pada Kelompok B Taman Kanak-kanak Labschool STAI Bani Saleh, perumahan Villa Taman Kartini Bekasi. Menggunakan metode penelitian deskriptif kualitatif. Pengumpulan data menggunakan wawancara, dokumentasi, dan catatan lapangan. Komponen yang diamati terdiri dari; filosofi implementasi model sentra, strategi implementasi model sentra, media sarana dan prasarana dalam Implementasi model sentra, peran guru dalam Implementasi model Sentra, kebijakan implementasi model sentra, dan evaluasi model sentra. Hasil penelitian didapatkan bahwa TK Labschool STAI Bani Saleh telah mengimplementasikan pembelajaran sentra dengan baik sesuai dengan kaidah yang dtentukan. .
\end{abstract}

Kata Kunci: model sentra; anak-anak; taman kanak-kanak

\begin{abstract}
This study aims to describe the Implementation of the Center Learning Model which was carried out in the Group B Kindergarten Labschool STAI Bani Saleh, residential Taman Kartini Bekasi. Using descriptive qualitative research methods. Data collection uses interviews, documentation, and field notes. Components observed consisted of; philosophy of the implementation of the center model, the strategy of implementing the center model, media of facilities and infrastructure in the implementation of the center model, the role of the teacher in the Implementation of the Center model, the policy of implementing the center model, and the evaluation of the center model. The results showed that TK Labschool STAI Bani Saleh had implemented the learning center well according to the rules set.
\end{abstract}

Keywords: centra model; children; kingdergarten

Copyright (c) 2019 Sri Watini

$\triangle$ Corresponding author :

Email Address : srie.watini@gmail.com ( Jalan Patuha Utara Kayuringinjaya Bekasi )

Received 7 May 2019, Accepted 10 October 2019, Published 10 October 2019

\section{PENDAHULUAN}

Pendidikan adalah suatu proses bagaimana mengubah kehidupan seorang anak menjadi lebih baik, mandiri dan bertanggungjawab. Berkualitas atau tidaknya kehidupan seseorang di masa depannya ditentukan oleh pendidikan awal sebagai pendidikan landasannya. Pendidikan anak usia dini adalah pendidikan paling mendasar sebagai peletakan pondasi kehidupan. (Dimyati, 2018) Pemberian rangsangan atau stimulasi dalam 
rangka intervensi dan deteksi dini adalah fokus edukasi dalam mengembangkan seluruh aspek-aspek perkembangan yang ada pada anak agar semua potensi yang dimiliki dapat berkembang secara optimal. Anak pada masa usia dini merupakan masa yang paling tepat untuk menanamkan nilai-nilai pada anak baik untuk perkembangan intelektual, sosial, emosional, bahasa, norma, dan agama. Usia dini adalah usia emas (golden age) dimana tahap ini efektif untuk menstimulasi anak dengan unsur kebaikan. (Islamiah, Firdani, \& Asep, 2019)

Kesadaran para orang tua akan arti pentingnya pendidikan anak usia dini pada saat ini meningkat seiring dengan bertambahnya jumlah lembaga penyelengara PAUD yang terus bertambah di wilayah-wilayah seluruh Indonesia. Hal ini diperkuat dengan adanya regulasi tentang kebijakan pemerintah dalam Undang-undang Sistem Pendidikan Nasional No. 20 Tahun 2003 Bab 1 Pasal 1 butir 14 tentang Pendidikan Anak Usia Dini yang menyatakan bahwa, "Pendidikan anak usia dini adalah upaya pembinanaan yang ditujukan kepada anak sejak lahir sampai dengan usia enam tahun yang dilakukan melalui pemberian rangsangan pendidikan untuk membantu perkembangan jasmani dan rohani agar anak kelak memiliki kesiapan dalam memasuki pendidikan lebih lanjut"(Indonesia, 2003) . Besarnya animo kesadaran masyarakat terhadap pentingnya pendidikan anak usia dini menjadi dasar bagi penyelenggara pendidikan untuk menyelenggarakan proses pendidikan anak usia dini yang berbeda serta memiliki karakteristik atau kekhasan sebagai daya tarik lembaga sehingga dapat menjadi daya pilihan atau option bagi para orang tua atau stakeholder untuk memasukkan putra putrinya pada lembaga pendidikan yang diselenggarakan. Pada saat ini banyak lembaga pendidikan anak usia dini yang berdiri sehingga menjadi suatu persaingan yang sangat ketat. Oleh sebab itu lembaga penyelenggara harus mampu memberikan dan menawarkan program-program unggulan yang menarik serta dilaksanakan secara profesional. Salah satu program unggulan yang diterapkan adalah model sentra.

Model sentra merupakan model pembelajaran yang dikembangkan oleh Dr. Helen Parkhurst di Amerika pada tahun 1904 melalui Sekolah Sistem Dalton. Sistem kelas Dalton berbeda dengan sekolah biasa yang menerapkan sistem klasikal. Sekolah Dalton menggunakan ruangan-ruangan atau vak-vak, ada ruangan khusus sejarah, ilmu bumi, ilmu pengetahuan alam selanjutnya untuk tiap vak ada ruangannya sendiri. (Soejono, 1978). Dalam Pendidikan Anak Usia Dini (PAUD) selanjutnya Model Sentra dikenal dengan istilah Beyond Centers and Circle Time (BCCT) atau sentra dan lingkaran. Penemu model BCCT adalah Dr. Pamela Phelps seorang tokoh pendidikan dari Amerika Serikat dan mengimplemetasikan model ini pada Creative Pre-school di Tallahase Florida. Model pembelajaran sentra menggunakan sentra-sentra atau vak-vak dan dalam perkembangannya menggunakan ruang-ruang kelas yang berbeda dalam tujuan pembelajaran yang sama dimulai dari ruang kelas klasikal yang membahas topik atau tema pokok bahasan dan dikembangkan serta dibahas dalam proses pembelajaran selajutnya pada ruang-ruang kelas atau sentra-sentra yang berbeda. Dalam pendidikan anak usia dini implemetasi sentra dikenal dengan istilah pijakan. Menurut Dirjen PAUD, " pijakan adalah dukungan yang berubah-ubah yang disesuaikan dengan perkembangan yang dicapai anak yang dijadikan sebagai pijakan untuk mencapai perkembangan yang lsebih tinggi (PAUD, Dirjen, 2006). Pijakan yang dipakai pada model sentra PAUD terdiri dari empat pijakan yaitu; 1) pijakan lingkungan main, 2) pijakan sebelum main, 3) pijakan selama main dan 4) pijakan setelah main (PAUD, Dirjen, 2006). Model sentra dapat menjadi alternatif model pembalajaran PAUD

Jika bicara tentang anak maka terlintas dalam pemikiran bahwa anak adalah manusia kecil yang selalu bermain setiap saat untuk mencoba segala sesuatu yang terkadang nampak serius, tiba-tiba tertawa sendiri, bicara sendiri, namun mudah menangis saat sesuatu keadaan tidak sesuai dengan keinginan atau harapannya. Secara tradisional anak usia dini memiliki makna bahwa, "Anak adalah manusia dewasa mini, masih polos dan belum bisa 
apa-apa atau dengan kata lain belum mampu berpikir. Anak merupakan manusia yang memiliki potensi yang masih harus dikembangkan (Hartati, 2005). Anak usia dini adalah anak yang sedang mengalami perkembangan dan pertumbuhan yang sangat pesat. Hal ini diperkuat dengan pernyataan anak usia dini merupakan masa emas, masa ketika anak mengalami pertumbuhan dan perkembangan yang pesat, anak usia dini mampu mengembangkan pengetahuan yang sudah diketahui dengan pengetahuan baru yang diperolehnya, dan mengembangkan kemampuan memahami sesuatu dengan cara melihat bermacam- macam hubungan antara suatu objek dengan objek yang lainnya berdasarkan perbedaan dan persamaan. (Aprinawati, 2017) Masa golden ages atau masa emas sangat dikenal sebagai penanda atau karakteristik perkembangan anak yang tidak ada dalam rentang kehidupan manusia. Hakikat Anak Usia Dini menurut Yuliani dalam menyatakan bahwa, "anak usia dini adalah sosok individu yang sedang mengalami suatu proses perkembangan dengan pesat dan fundamental bagi kehidupan selanjutnya.(Yuliani Nurani Sujiono, 2013)

Menurut NAEYC (National Assosiation Education for Young Children) dalam Hartati menyatakan bahwa, "Anak usia dini adalah sekelompok individu yang berada pada rentang usia antara 0-8 tahun. (Hartati, 2005) Layanan pendidikan wajib dan harus diberikan baik dalam bentuk informal, non formal maupun formal. Pada anak usia dini 4-6 tahun maka pendidikan yang tepat sesuai dengan kebijakan pemerintah adalah mengikuti pendidikan formal berupa Taman Kanak-kanak.

Taman kanak-kanak (TK) merupakan bagian dari Pendidikan Anak Usia Dini di jalur Formal. Pendidikan Taman Kanak-kanak memiliki dua kelompok usia yaitu usia 4-5 tahun dalam kelompok kelas TK A dan usia 5-6 tahun dalam kelas kelompok B. Dalam regulasi atau kebijakan di Indonesia anak usia dini adalah anak yang memiliki rentang usia 0-6 tahun. (Depdikbud, 2014) Hal ini tertera dalam ketetapan Undang-undang Sistem Pendiidkan Nasional No. 20 Tahun 2003 pasal 1 ayat 14 yang berbunyi, Pendidikan Anak Usia Dini adalah upaya pembinaan yang ditujukan kepada anak sejak lahir sampai dengan usia enam tahun yang dilakukan melalui pemberian rangsangan pendidikan untuk membantu pertumbuhan dan perkembangan jasmani dan rohani anak agar anak memiliki kesiapan dalam memasuki pendidikan lebih lanjut (Heny Djoehani, 2005) Dalam pasal 28 ayat (1). "Pendidikan anak usia dini diselenggarakan sebelum jenjang pendidikan dasar, ayat (2), " Pendidikan anak usia dini dapat diselenggarakan melalui jalur pendidikan formal, non formal, dan/atau informal, ayat (3). "Pendidikan anak usia dini di jalur formal berbentuk Taman Kanak-kanak (TK) , Raudhatul Athfal (RA), atau bentuk lain yang sederajat. (Guza, 2005) Taman Kanak-kanak (TK) menurut Syaodih menyatakan, "Taman Kanak-kanak adalah lembaga pendidikan yang ditujukan bagi anak-anak usia 4-6 tahun untuk melaksanakan suatu proses pembelajaran agar anak dapat mengembangkan potensinya sejak usia dini sehingga dapat berkembang secara wajar sebagai seorang anak. (Syaodih, 2005) Pendidikan anak usia dini khususnya Taman Kanak-kanak adalah pendidikan yang diselenggarakan dengan tujuan untuk menfasilitasi pertumbuhan dan perkembangan anak secara menyeleuruh atau menekankan pada perkembangan seluruh kepribadian anak sebagaimana yang dikemukakan oleh Anderson (1993) dalam (Heny Djoehani, 2005), " Early childhood education is based on a number of methodical didactic consideration the aim of which is provide opportunities for development of children personality." (Heny Djoehani, 2005). Artinya adalah bahwa pendidikan usia dini khususnya Taman Kanak-kanak memberikan kesempatan untuk mengembangkan kepribadian anak, oleh karena itu pendidikan untuk anak usia dini khususnya Taman Kanak-kanak perlu menyediakan berbagai kegiatan yang mengembangkan berbagai aspek perkembangan yang meliputi aspek kognitif, bahasa, sosial, emosi, fisik dan motorik.

Setiap tahapan perkembangan tiap anak memiliki tugas-tugas yang berbeda sesuai dengan tahapan atau tingkatan usianya. Hal ini juga terjadi pada anak usia Taman Kanakkanak yang tentunya memiliki tugas-tugas perkembangan yang khas atau memiliki 
kharakteristik tersendiri. Dalam implementasi pengembangan aspek-aspek potensi yang ada pada anak dilaksanakan dengan prinsip bermain sambal belajar, bernyanyi dan bergerak sehingga dapat menarik minat anak dalam belajar. Usia 4-6 tahun merupakan masa peka yang penting bagi anak untuk mendapatkan pendidikan. Pengalaman yang di peroleh anak dari lingkungan, termasuk stimulasi yang diberikan oleh orang dewasa, akan mempengaruhi kehidupan anak di masa yang akan datang. Oleh karena itu diperlukan upaya yang mampu memfasilitasi anak dalam masa tumbuh kembangnya berupa kegiatan pendidikan dan pembelajaran sesuai dengan usia, kebutuhan dan minat anak. (Roza, 2012)

Dalam penelitian ini memiliki beberapa pertanyaan penelitian antara lain: 1). filosofi apa yang mendasari implementasi Model Sentra di TK Labschool STAI Bani Saleh?, 2). bagaimana implementasi strategi model sentra di TK Labschool STAI Bani Saleh? 3). bagaimana sistem pengaturan waktu dalam pengelolaan pembelajarannya?, 4). apa peran guru atau pendidik dalam implementasi Model Sentra di TK Labschool STAI Bani Saleh?, 5). bagaimana karakteristik media dan sumber belajar yang mendukung implementasi model sentra ,6). bagaiman regulasi mengenai implementasi Model Sentra, 7). bagaimana bentuk evaluasi dalam implementasi Model Sentra?

\section{METODOLOGI}

Metode yang digunakan dalam penelitian ini adalah metode penelitian Deskriptif. Metode deskriptif adalah suatu metode dalam meneliti status sekolompok manusia, suatu objek, suatu set kondisi, suatu sistem pemikiran, atau suatu kilas peristiwa pada masa sekarang (Nazir, 2005). Whitney dalam Nazir: 2005 menyatakan bahwa, “Metode deskriptif adalah pencarian fakta dengan interprestasi yang tepat. (Nazir, 2005)

Menurut Nazir, 2005,"Metode Deskriptif adalah metode yang membuat gambaran atau lukisan secara sistematis, faktual, dan akurat mengenai fakta-fakta, sifat-sifat serta hubungan antar fenomena yang diselidik. (Nazir, 2005). Dalam penelitian ini peneliti menerapkan deskriptif kwalitatif yang akan memberikan data-data atau dokumen secara lengkap, teratur, bertahap, dan berkesinambungan sehingga mampu memberikan informasi yang valid, dapat dipercaya, otentik dan bisa dibuktikan kebenarannya.

Teknik pengumpulan data menggunakan interview atau wawancara, observasi dan dokumentasi. Interview atau wawancara yang sering dikenal dengan interview lisan adalah sebuah dialog yang dilakukan oleh pewawancara (interviewer) untuk memperoleh informasi dari terwawancara. Ada beberapa bentuk menurut Arikunto antara lain1). interview bebas (inguided interview), 2). interview terpimpin (guided interview), 3). interview bebas terpimpin.(Dimyati, 2018) Interview bebas merupakan interview atau wawancara yang menanyakan apa saja namun masih tetap fokus pada akar permasalahan. Pada jenis interview ini pewancara tanpa menggunakan acuan berupa sederatan pertanyaanpertanyaan. Interview terpimpin (guided interview) merupakan bentuk interview dengan menggunakan sederatan pertanyaan yang berkaitan dengan data yang akan dikumpulkan dengan pertanyaan yang lengkap dan terstruktur. Sedangkan interview bebas terpimpin yaitu kombinasi antara interview bebas dan interview terpimpin.

Teknik analisis data dalam penelitian ini adalah data-data yang telah terkumpul dengan rapi diberikan pengkodean agar memudahkan dalam melakukan pengelompokkan ataupun identifikasi. Adapun masing-masing pengkodean tersebut adalah 1). Catatan Wawancara disingkat (CW), Catatan Dokumentasi (CD) dan Catatan Lapangan (CL). Penelitian ini dilaksanakan di TK Labschool STAI Bani Saleh, Villa Taman Kartini Bekasi pada tahun 2015. 


\section{HASIL DAN PEMBAHASAN}

\section{Persepsi Guru tentang Model Pembelajaran Sentra}

Model Pembelajaran Sentra adalah adalah suatu bentuk atau pola pembelajaran yang menggunakan sentra-sentra atau vak-vak di mana penamaanya bisa berdasarkan pada rumpun pengembangan, aktivitas atau bidang studi di mana guru memiliki tugas yang lebih berat dibandingkan tanpa menerapkan model sentra. Guru selain menjadi guru kelas juga sebagai guru sentra. Guru sentra harus betul-betul menguasai bidang kesentraanya atau bidang keahliannya (CW.1).

TK Labschool STAI Bani Saleh menggunakan ruangan-ruangan kelas yang terpisah dalam pelaksanaan kegiatan sentra (CD.2, CL.2).

Berdasarkan pada temuan CW.1, CD.2, CL.2 maka implementasi Model Pembelajaran Sentra membutuhkan adanya ruangan dalam proses pelaksanaanya. Jika lembaga memiliki satu ruangan yang luas maka dalam pembelajaran cukup membuat sekat-sekat, vak-vak atau area-area di pojok-pojok ruangnya. Jika lembaga tidak memiliki satu ruangan yang besar maka dapat menggunakan ruang-ruang gedung yang terpisah-pisah dan berbedabeda letaknya namun masih dalam satu lokasi lembaga seperti gedung A untuk Sentra Sains, gedung B untuk Sentra Matematika dan sebaginya. Setiap ruangan sentra atau vak-vak harus ada guru sentra yang memiliki keahlian sesuai dengan bidang kesentraannya. Menurut Latif, Zukhairini, Rita Zubaidah dan Muhammad Effendi," Area kegiatan merupakan pusat-pusat belajar yang diberi tanda di dalam kelas, diisi dengan berbagai jenis kegiatan belajar dan alat-alat berdasarkan pada program kemampuan dasar tiap kelas, serta pada tema dan sub tema yang sedang dalam pembahasan (Latif, M, Zukhairini, Rita Zubaidah, Muhammad Affandi, 2013). Penamaan sentra boleh berdasarkan kesepatan guru atau lembaga pada saat awal implementasi Model Sentra yang digunakan. Adapun penamaan sentra dapat didasarkan pada bidang studi, aktivitas atau kegiatan serta bidang pengembangan seperti sentra sains, sentra matematika, sentra seni dan lain-lain. Menurut Soejono, "Dalam sekolah sentra sistem Dalton pengajaran diawali dengan proses klasikal setelah itu menggunakan ruangan-ruangan atau vak. Ada ruang sejarah, ilmu bumi, pengetahuan alam untuk tiap vak atau ruang yang berbeda. Guru dalam setiap vak harus ahli dibidangnya dan cinta pada vaknya. . (Soejono, 1978). Pengajaran dimulai dari proses klasikal untuk memberikan penjelasan umum. Adapun di kelas klasikal kegiatanya seperti gerak badan, menyanyi, bercerita, menghitung dan mencongak "Macam-macam area-area kegiatan di dalam kelas antara lain 1).area seni, 2). area balok, 3). area penemuan sains, 4). area bermain, 5). area Bahasa dan 6). area meja permainan. (Soejono, 1978).

Berdasarkan pada CW.1, CW.3, CD. 1, CL.1 ada beberapa landasan filosofi dalam impelementasi di TK Labshool STAI Bani Saleh Bekasi hal ini selaras dengan sistem Sentra Dalton walaupun belum secara keseluruhan atau sebagian saja. Dalam filosofi landasan implementasi Model Dalton secara terperinci antara lain, 1). keaktifan atau otoaktivitas anak adalah faktor yang sangat penting untuk menumbuhkan sifat-sifat watak yang baik dalam jiwa anak, 2). anak diberikan kemerdekaan dan kebebasan pada waktu menunaikan kwajibannya, 3). pengajaran harus disesuaikan dengan sifat masing-masing individu yang mempunyai tempo dalam belajarnya sendiri dan kegemarannya sendiri. Parkhurst menamakan rencananya sebagai suatu sistem belajar sendiri atau mandiri, 3. pengajaran klasikal tidak dihilangkan namun penerapannya lebih longgar dalam rangka memberikan kebebasan pada murid untuk tidak terikat oleh guru, urutan bahan ajar yang akan dipelajari, alat pengajaran serta kemajuan serta bakat murud-murid. Untuk itu dikatakan bahwa sistem Dalton merupakan sistem pengajaran yang merupakan perpaduan antara klasikal dan perorangan, 4. sifat perorangan harus diimbangi dengan latihan-latihan untuk 
menumbuhkan rasa sosial, rasa bekerjasama guna kepentingan bersama sesuai dengan dasar didaktif kooperatif kebersamaan (Yuliani Nuraini Sujiono, 2009). Menurut Hartati, "Secara psikologi anak TK adalah anak usia dini yang memiliki keingintahuan yang sangat tinggi (Hartati, 2005). Dalam mengakomodasi keingintahuannya maka rancangan lingkungan belajar anak perlu dikondisikan secara bervariasi dan menarik minat anak untuk mempelajarinya. Variasi sentra akan membantu perkembangan anak secara optimal.

\section{Implementasi Strategi Model Sentra}

Pelaksanaan Kegiatan

Filosofi yang mendasari penyelenggaraan Model Sentra di TK Labschool STAI Bani Saleh ditinjau berdasarkan pada segi psikologis anak, perkembangan anak, bahan materi dan bahan kajian tentang anak serta segi kegiatan pembelajaran yang dilakukan (CW.1)

Setiap sentra memiliki bahan atau kajian yang fokus untuk dipelajari. Oleh sebab itu dalam nroses nembelaiaran diısahakan anak melakıkan keqiatan belaiar terfok11s (CW.5).

Pelaksanaan kegiatan pembelajaran di TK Lab School STAI Bani Saleh diawali dengan kegiatan klasikal kelas sesuai dengan sentra masing-masing di mana pembagian sentranya sudah ditetapkan oleh guru mulai anak masuk sekolah (CD.3, CL.3)

Kegiatan sentra sudah ditentukan atau ditetapkan sejak awal pada anak masuk TK Labschool STAI Bani Saleh, hal ini mengingat jika anak diberikan kebebasan untuk memilih sendiri yang dikehendaki maka ada kecendurungan untuk memilih satu atau dua sentra saja (CW.4)

Berdasarkan pada temuan CD.3, CL.3,CW.3 dan CW.5 implementasi model sentra di TK Labshool STAI Bani Saleh mengikuti prinsip-prinsip dalam aturan strategi model sentra, namun belum secara keseluruhan. Pelaksanaan kegiatan sudah dimulai dengan kegiatan klasikal. Setelah kegiatan klasikal dilanjutkan dengan kegiatan sentra-sentra. Namun kegiatan sentra bukan berdasarkan pilihan anak sesuai dengan kontrak di awal seperti pada sistem sentra Dalton, namun di TK Labschool STAI Bani Saleh ditentukan oleh kesepatan guru dan kesepakatan lembaga di awal tahun ajaran. Hal ini mengingat jika anak diberikan kebebasan untuk memilih sendiri sentra yang dipili, maka dikhawatirkan adanya kecenderungan pada anak hanya memilih satu atau dua sentra saja. Usia anak TK adalah usia perkembangan di mana semua aspek potensi sangat diperlukan stimulasi agar semua aspek berkembang secara optimal. Hal ini sejalan dengan pendapat montesori di mana anak usia 0-6 tahun dikatakan sebagai masa peka. Menurut Hapidin, "Masa peka adalah suatu masa di mana munculnya berbagai potensi yang tersembunyi atau (hidden potency) atau suatu kondisi di mana suatu fungsi jiwa membutuhkan rangsangan tertentu untuk berkembang."(Hapidin, 1999). Dengan memasuki sentra-sentra yang berbeda dengan kondisi dan situasi yang berbeda maka akan memberikan pengaruh positif dalam meningkatkan kemampuan atau potensi anak. Menurut Berg dalam Hartati," Sepuluh menit adalah waktu bagi anak sekitar 5 tahun untuk dapat duduk dan memperhatikan sesuatu secara nyaman (Hartati, 2005). Agar anak dapat duduk dengan berkonsentrasi maka lingkungan harus dikondisikan menarik perhatian dan bervariasi.

\section{Waktu Pelaksanaan}

Waktu pelaksanaan Sentra di TK Labschool STAI Bani Saleh adalah Hari Senin, Selasa, Rabu dan Kamis (CW.6, CD.4) 
Berdasarkan hasil temuan CW.6, CD.4 bahwa pelaksanaan sentra di TK Labschool STAI Bani Saleh belum dilaksanakan full setiap hari. Hal ini berbeda dengan sentra yang sesungguhnya di mana pelaksanaannya full dalam satu minggu, satu bulan dan satu tahun. Pada saat kontrak awal pengajaran anak sudah mendapatkan bahan, materi yang akan dipelajari selama mengikuti kegiatan di sekolah. Intisari dari sistem Dalton adalah bahan pengajaran yang diberikan sekaligus dalam bentuk tugas untuk tahunan, bulanan dan mingguan (Soejono, 1978). Dalam sumber yang lain menyatakan bahwa, "Satu kelompok akan menghabiskan waktu bermain mereka dalam satu sentra setiap harinya (Latif, $\mathrm{M}$, Zukhairini, Rita Zubaidah, Muhammad Affandi, 2013).

\section{Jumlah Sentra dan Nama Sentra}

Jumlah Sentra yang berada di TK Labschool STAI Bani Saleh ada 6 dan nama-namanya adalah sebagai berikut: 1). Sentra Al-Islam, 2). Sentra Sosial Studi, 3). Sentra Bahasa, 4). Sentra Matematika, 5). Sentra Art atau Seni dan Sentra Sains. Penamaan sentra berdasarkan pada bidang pengembangan atau bidang studi (CW.7, CD.5, CL. 4)

Berdasarkan hasil temuan CW.7, CD.5, CL. 4 penamaan model sentra sudah sesuai dengan Sentra model Dalton seperti ruang sentra sejarah, ilmu bumi dan lain-lain. Hal ini berbeda dengan sistem yang dikembangkan oleh Pamela A Coughlin dkk yang menyatakan bahwa pusat kegiatan bervariasi dari satu kelas ke kelas lainnya namun semua kelas memiliki pusat-pusat kegiatan seperti pusat kesenian, pusat permainan balok, pusat memasak, pusat bermain drama, pusat bermain musik, pusat kegiatan di luar kelas seperti pusat bermain air (Pamela Coghlin, 2000). Adapun implementasi sentra di Indonesia yang rancang oleh Dr. Pamela Pelp pada sekolah Ciracas Jakarta Timur memiliki tujuh sentra antara lain 1). sentra persiapan, sentra balok, sentra main peran besar, sentra main peran kecil, sentra bahan alam, sentra seni, sentra imtaq (Latif, M, Zukhairini, Rita Zubaidah, Muhammad Affandi, 2013).

\section{Keterlibatan Anak dalam Model Sentra}

Keterlibatan anak dengan diterapkannya Model Sentra lebih optimal dalam mengembangkan aspek-aspek potensi yang ada baik terlibat secara fisik, mental maupun sosial-emosionalnya. Setiap kegiatan anak nampak lebih antusias dan semangat. Anak-anak selalu ingin belajar dan berada di sekolah (CW.8, CL.5)

Berdasarkan pada CW.8, CL.5 anak-anak nampak aktif dalam setiap kegiatan pada masing-masing sentra. Hal ini dipengaruhi oleh setiap ruang atau sentra memiliki kekhasan masing-masing sehingga mengurangi rasa kebosanan pada anak yang ingin selalu melakukan kegiatan yang bervariasi, menarik dan tidak monoton. Menurut Masitoh \& Ocih Setiasih, Heny Djoehani, 2005, "strategi untuk menciptakan pendekatan belajar aktif adalah suatu pendekatan yang direncanakan sedemikian rupa sehingga proses belajar yang berlangsung benar-benar dapat mendukung perkembangan dan belajar anak secara optimal (Masitoh, Ocih Setiasih, Heny Djoehani, 2005).

Strategi pembelajaran yang dimaksud menurut Kemp (1995) dalam Majid," adalah suatu kegiatan pembelajaran yang harus dikerjakan oleh guru dan peserta didik agar tujuan pembelajaran dapat dicapai secara efektif dan efisien (Majid, 2013). Menurut Majid, " pembelajaran adalah upaya pendidik untuk membantu peserta didik untuk melakukan kegiatan belajar. Menurut JR.David, 1976 dalam Wina Sanjaya," a plan method, or series of activities designed to archives articular educational goal." artinya ,"strategi pembelajaran dapat diartikan sebagai perencanaan yang berisi tentang rangkaian kegiatan yang didesain untuk mencapai tujuan pendidikan tertentu. Adapun pendekakan (approach) dapat diartikan sebagai titik tolak atau sudut pandang kita terhadap proses pembelajaran. Dalam implementasi strategi pembelajaran serta metode yang digunakan tergantung dari pendekatan tertentu. (Sanjaya, 2006). 


\section{Pengaturan Waktu Kegiatan dalam Model Sentra}

\begin{tabular}{|c|c|c|c|}
\hline No & Time & & Daily Activity \\
\hline 1 & $\begin{array}{l}07.30 \\
08.00\end{array}$ & - & Morning Journal \\
\hline 2. & $\begin{array}{l}08.00 \\
08.15\end{array}$ & - & Diciplin Activity Program \\
\hline 3. & $\begin{array}{l}08.15 \\
08.30\end{array}$ & - & Circle Time \\
\hline 4. & $\begin{array}{l}08.30 \\
09.10\end{array}$ & - & Center Activiti 1 \\
\hline 5. & $\begin{array}{l}09.10 \\
10.00\end{array}$ & - & Center Activity 2 \\
\hline 6. & $\begin{array}{l}10.00 \\
10.50\end{array}$ & - & Break Time \\
\hline 7. & $\begin{array}{l}10.50 \\
11.30\end{array}$ & - & Center Activity 3 \\
\hline 8. & $\begin{array}{l}11.30 \\
12.00\end{array}$ & - & $\begin{array}{l}\text { Sholat Berjamaah dan } \\
\text { Da`wah Activity (CW. 9, } \\
\text { CL.6, CD.6) }\end{array}$ \\
\hline
\end{tabular}

Berdasarkan pada temuan CW. 9, CL.6, CD.6 maka dapat dikatakan bahwa pengaturan kegiatan mengacu pada kegaiatn sentra yang dikembangkan oleh Pamela Coughlin dkk. Hanya saja TK Labschool STAI Bani Saleh mengkolaborasikan dengan kegiatan keaagamaan yaitu kegiatan sholat berjamaah dan da wah activity. Dalam rancangan kegiatan menurut Pamela Coughlin untuk anak usia TK 5-6 tahun adalah sebagai berikut:

Tabel 2 Rancangan Kegiatan menurut Pamela Coughlin

\begin{tabular}{ll}
\hline Waktu & Kegiatan \\
\hline $9.00-9.15$ & Pertemuan pagi : anak-anak berbagi berita dan cerita \\
$9.15-10.30$ & Pilihan pekerjaan : Anak-anak bekerja pada sentra sesuai pilihan \\
$10.30-$ & Beres-beres kudapan \\
11.00 & \\
$11.00-$ & Pilihan kegiatan luar ruangan \\
12.00 & \\
$12.00-$ & Membersihkan diri, menyiapkan Meja dan Makan siang \\
12.45 & \\
$12.45-1.45$ & Waktu cerita bersama atau baca buku \\
$1.45-2.30$ & Waktu tenang dan istirahat \\
$2.30-3.10$ & Pilihan Kerja lanjutan \\
$3.10-3.30$ & Beres-beres kudapan \\
$3.30-4.15$ & Pilihan kegiatan luar ruangan \\
$4.15-4.45$ & Waktu kelompok (diskusi kegiatan hari itu, menyanyi dan mendengarkan \\
& cerita, serta permainan \\
$4.45-5.30$ & Rehat Waktu dengan anggota keluarga \\
\hline Coughlin dkk (Caughlin, Pamela, Kristin A, Hensen, Dinah Heller, Roxana, 2000)
\end{tabular}


Pengaturan waktu kegiatan yang nampak di atas adalah jenis kegiatan program untuk fullday school sedangkan implementasi sentra di TK Labschool STAI Bani Saleh masih bersifat halfday school bahkan terkadang masih dengan sistem konvensional yang ditetapkan oleh pemerintah.

\section{Pihak-pihak yang terlibat dalam Implementasi Model Sentra}

Dalam melaksanakan Model Sentra di TK Labschool STAI Bani Saleh membutuhkan kerjasama yang baik dengan orang tua atau wali murid, guru, kepala sekolah, TU, tukang kebun, lembaga-lembaga terkait dalam pengembangan pertumbuhan dan perkembangan anak seperti puskesmas, industri kecil, seperti pabrik tempe, susu dan sebagainya serta masyarakat (CW.10)

Sesuai dengan temuan penelitian CW.10 semua komponen dalam model sentra di TK Labschool STAI Bani Saleh harus melibatkan semua pihak dalam berperan serta untuk mendukung implementasi kegiatannya. Jika dikaitkan dengan implementasi sesuai model BCCT (beyond centers and circle time) dalam Caoughlin dkk, "peran keluarga adalah menjadi faktor utama dalam implementasi model sentra. Keluarga memiliki pengaruh terbesar dalam perkembangan anak. Untuk itu lembaga yang menerapkan model sentra memiliki ruang khusus keluarga sebagai tempat komunikasi antara orang tua atau wali dengan staf pengajar. Di samping itu ada komite penasehat keluarga di sekolah. (Caughlin, Pamela, Kristin A, Hensen, Dinah Heller, Roxana, 2000).

\section{Media, Sarana dan Prasarana dalam Implementasi Model Sentra}

Tabel 3 Media yang digunakan dalam Model Sentra

\begin{tabular}{|c|c|c|}
\hline No & Sentra & Media \\
\hline 1. & Bahasa & $\begin{array}{l}\text { 1.White Board, 2.Spidol, 3. Balok Huruf, 4.Kertas Warna-warni, 5. Foto-foto dan } \\
\text { nama anak, 6. Puzle Huruf, 7. Kartu Kata, 8.Kartu Gambar, 9. Kartu Suku Kata, } \\
\text { 10. Buletin Board dll }\end{array}$ \\
\hline 2. & Matematika & $\begin{array}{l}\text { 1.Bentuk-bentuk Geometri, 2.Puzle duplek keeping, 3. Ragam bentuk Kancing } \\
\text { Baju, 4.Puzle Angka, 5. Kartu Lambang Bilangan, 6. Balok Kayu, 7. Lembar } \\
\text { Hitung, 8. Menara Kayu segi empat, 9. Kipas Hitung, 10. Batu-batu Aquarium } \\
\text { warna-warni dll }\end{array}$ \\
\hline 3. & Al- Islam & $\begin{array}{l}\text { 1.Miniatur Masjid, 2.VCD-VCD Ke-Islaman, 3.CD Manasik Haji, 4. Kartu Huruf } \\
\text { Hijaiyah, 5.Balok-balok huruf hijaiyah dll }\end{array}$ \\
\hline 4. & Seni & $\begin{array}{l}\text { 1.Cat Air, cat minyak, kuas, 2. Buku Gambar, 3.Pewarna Makanan, 4. Gunting, } \\
\text { 5. Krayon, 6. Macam-macam tali/benang, 7. Biji-bijian, 8. Sikat gigi bekas, } 9 . \\
\text { Karet Gelang, 10.Celemek, 11.Cotton Bud, 12. Lilin, 13. Sisi dan dll }\end{array}$ \\
\hline 5. & Sains & $\begin{array}{l}\text { 1.Lub/kaca pembesar, 2.Cermin, 3.Gelas ukur dari plastic, 4. Miniatur gigi } \\
\text { manusia, 5..Jam Bekas dll }\end{array}$ \\
\hline 6. & Sosial Studi & $\begin{array}{l}\text { 1.Panggung, } 2 \text {. Alat mainan dokter-dokteran, 2. Alat mainan masak-masakan, } 5 . \\
\text { Alat mainan rumah tangga, } 6 \text {. Alat mainan transportasi, } 7 \text {. Miniatur Rumah- } \\
\text { rumahan (CW. 10, CL.7, CD.7) }\end{array}$ \\
\hline
\end{tabular}

Berdasarkan hasil temuan CW. 10, CL.7, CD.7 media-media dalam setiap sentra sudah sesuai dengan implemntasi sentra berdasarkan pada bidang sentra yang ada dan dikembangkan oleh lembaga atau sekolah di TK Labschool STAI Bani Saleh. Menurut Latih Zukhairini, Rita Zubaidah, Muhammad Affandi,"Guru harus dapat memilih media dan sumber belajar yang dapat mendukung terlaksananya proses belajar yang efektif dan relevan dengan metode pembelajaran yang dipilih dan mendukung peningkatan tahap perkembangan anak menuju ke tahap yang lebih tinggi.". (Latif, M, Zukhairini, Rita Zubaidah, Muhammad Affandi, 2013). Batasan media dalam AECT (association of education and communication technologie, 1997) dalam Arsyad, "media adalah bentuk dan saluran yang 
digunakan untuk menyampaikan pesan atau informasi. Menurut Gagne dan Briggs, 1975 dalam Arsyad menyatakan," media pembelajaran meliputi alat yang secara fisik digunakan untuk menyampaikan isi materi pengajaran yang terdiri antara lain: buku, tape recorder, kaset, video camera, video recorder, film slide ( gambar bingkai), foto, gambar grafik, televise dan computer. Media juga dikatakan sebagai sumber belajar atau wahana fisik yang mengandung materi instruksional di lingkungan siswa dalam rangka menstimulasi atau merangsang anak dalam belajar. (Latif, M, Zukhairini, Rita Zubaidah, Muhammad Affandi, 2013).

\section{Sarana dan Prasarana yang digunakan dalam mendukung Model Sentra}

Sarana dan Prasana dalam implementasi Model Sentra diTK Lab School STAI Bani Saleh antara lain: 1) Gedung Permanen, 2). Ruang Laboratorium Komputer, 3). Ruang Perpustakaan Anak, 4). Peralatan Musik, 5). Drunband, 6). Kolam Renang, 7).Kebun Sekolah (Apotik Hidup), 8) dl (CW. 11, CL.8, CD.8)

Dari temuan CW. 11, CL.8, CD.8 maka dapat dikatakan bahwa Model Sentra di TK Labschool STAI Bani Saleh dapat diimplementasikan dengan baik mengingat sarana dan prasarana sudah mendukung secara proposional seperti ruang-ruang gedung dengan kwantitas yang cukup untuk penerapan model sentra. Sentra yang tepat dan dapat diterapkan menggunakan ruang-ruang gedung yang berbeda. Dengan lengkapnya sarana dan prasarana pendukung proses pembelajaran tentunya juga menjadi daya tarik bagi para orang tua atau stake holder karena performance sekolah yang tentunya meyakinkan. Suasana pembelajaran dalam bentuk lingkungan fisik dari sebuah lembaga Taman Kanak-kanak mencakup semua yang mengelilingi dan berada di sekitarnya. Termasuk di dalamnya lantai, dinding-dinding, bentuk serta ukuran ruangan belajar, taman, perabotan, bahan-bahan, perlengkapan dan mainan-mainan ikut membantu mempengaruhi pengalaman masa taman kanak-kanak. Penataan perabotan dapat memberi masukan mengenai penggunaan ruang, pengaruh keamanan, pengaruh dari jalan dan tingkat kebisingan (Sugiyanto, 1995). TK Labschool STAI Bani Saleh yang terletak di perumahan Villa Taman Kartini merupakan posisi yang tepat untuk implementasi model sentra. Walaupun pada saat hujan lebat terkadang terjadi banjir namun masih dapat diatasi dengan baik.

\section{Syarat Media, Sarana dan Prasarana dalam Model Sentra}

Syarat-syarat Pemilihan Media, Sarana dan Prasarana yang digunakan di TK Labschool STAI bani Saleh antara lain: Aman, sederhana dan mudah di dapat di sekitar lingkungan sekolah.

Berdasarkan pada temuan CW.12 media yang digunakan di TK Lab School STAI Bani Saleh sudah mendukung proses pembelajaran, akan tetapi perlu dikembangkan dan dijaga dengan baik. Syarat utama dalam pemilihan media harus benar-benar mengacu pada prinsip pemilihan media khususnya untuk anak usia dini. Segi keamanan baik media maupun sarana dan prasarana menjadi syarat utama dalam menentukan dan memilih media, sarana dan prasarana yang digunakan dalam pembelajaran. Media, sarana dan prasarana seharusnya memenuhi kriteria syarat APE (Alat Permainan Edukatif) yang tepat, efektif dan efisien. Menurut Mike Sigiyanto," APE (Alat Permainan Edukatif) adalah alat permainan yang dirancang secara khusus untuk kepentingan pendidikan dan mempunyai beberapa ciri antara lain: 1). dapat digunakan dengan berbagai cara, 2). ditujukan untuk anak-anak usia prasekolah yang berfungsi mengembangkan berbagai aspek perkembangan anak, 3). membuat anak terlibat aktif, 4). bersifat konstruktif dan 5). segi keamanan sangat diperhatikan. Adapun alat permainan yang tidak tepat baik yang diciptakan sendiri maupun dari lingkungan adalah 1). berbahaya, 2). pilihan orang tua, 3). terlalu sedikit jenisnya, 4). terlalu rumit, 5). tidak sesuai dengan usia kronologis anak, 5). terlalu mudah dan 6). rapuh (Sugiyanto, 1995). 


\section{Asal Usul atau Pengadaan Media, Sarana dan Prasarana dalam Model Sentra}

Pengadaan Media, Sarana dan Prasarana yang digunakan di TK Labschool STAI Bani Saleh berasal dari beberapa sumber antara lain: 1). Sumbangan Yayasasn, 2). Usaha Mandiri, 3). Orang Tua/ Wali, 4). Masyarakat Sekitar dan 5). Bantuan dari Pemerintah, 6).dll (CW. 13)

Berdasarkan pada CW.13 asal usul Pengadaan Media, Sarana dan Prasarana yang digunakan di TK Labschool STAI Bani Saleh berasal dari berbagai sumber. Semua dapat dijadikan sebagai sumber belajar dengan syarat dan ketentuan bahwa semua aman, sesuai dengan kebutuhan dan perkembangan anak serta sesuai dengan tujuan pembelajaran yang diharapkan serta relevan dengan kemampuan guru dalam mengimplementasikan. Latih Zukhairini, Rita Zubaidah, Muhammad Affandi,opcid mengatakan Prinsipnya 1). media harus bersifat multiguna, 2). media mudah didapat di lingkungan sekitar lembaga, 3). media tidak menggunakan bahan yang berbahaya, 4). mampu meningkatkan kreativitas anak, 5). sesuai dengan tujuan dan fungsi sarana, 6). dapat digunakan secara individu, kelompok maupun klasikal, 7) dibuat sesuai dengan tingkat perkembangan anak (Latif, M, Zukhairini, Rita Zubaidah, Muhammad Affandi, 2013).

\section{Pengaruh Media dalam Implementasi Model Sentra}

Bentuk peraturan dalam implementasi Model Sentra di Labschool Bani Saleh adalah berupa simbol-simbol, gambar-gambar, kalimat ajakan yang ditempel dalam dinding-dingding ruang sentra.(CW.18, 18, CL.9, CD.9)

Dalam implementasi Model Sentra dibutuhkan banyak media yang mendukung proses pembelajaran sesuai dengan tema dan kekhasan dari sentra-sentra. (CW.14)

Berdasarkan pada temuan CW.14 media dalam model sentra sangat dibutuhkan keberadaanya. Keberadaan media tidak dapat ditawar dan wajib ada dalam setiap sentra. Begitu juga dengan kwalitas harus terus diperhitungkan. Dalam implementasi model sentra di TK Labschool STAI Bani Saleh baik kwantitas maupun kwalitas perlu di jaga dan ditingkatkan. Pengaruh media dalam implementasi sentra disesuaikan dengan 1). definisi, 2). tujuan penggunaan media, 3). sesuai dengan aturan main yang berlaku di sentra, 4).relevan dengan manfaat media dalam sentra, 5). sesuai dengan kebutuhan belajar dan perkembangan anak, 6). sesuai dengan perlengkapan yang dibutuhkan dan keberadaannya dalam sentra, dan 7). relevan dengan kegiatan yang dilaksanakan dalam sentra masingmasing (Latif, M, Zukhairini, Rita Zubaidah, Muhammad Affandi, 2013).

\section{Peran Guru dalam Implementasi Model Sentra Peran Guru dalam Sentra}

Kriteria Guru dalam implementasi Model Sentra di TK Lab School STAI Bani Saleh adalah guru harus betul-betul menguasai bidang kesentraannya. (CW.16)

Peran Guru dalam implementasi Model Sentra di TK Lab School STAI Bani Saleh antara lain sebagai: 1) Fasilitastor, 2). Mediator, 3). Organsator, 4). Koordinator dan 5) Evaluator.

Berdasarkan CW.15 dan CW. 16 peran guru dalam sentra memiliki peran dan tugas yang agak berat dibanding pada saat tidak mengimplementasikan model sentra. Tidak saja sebagai guru kelas namun harus jadi guru sentra di mana dibutuhkan keahlian khusus atau kriteria khusus mengenai bidang kesentraannya. Menurut Soejiono,"tugas dan peran guru vak adalah seorang ahli di bidangnya dan mencintai vaknya. Guru dalam vak memiliki dan memegang kartu guru yang berisi catatan kemajuan semua murid mengenai vak yang dipegang oleh guru tersebut. (Sujiono, 2009). 


\section{Aturan atau kebijakan dalam Implementasi Model Sentra Pihak-pihak yang terlibat dalam pembuatan aturan dan bentuk aturannya}

Dalam pembuatan peraturan anaklah yang menjadi fokus atau diri mereka sendiri yang membuat dengan diskusi bersama. (CW.17)

Berdasarkan pada CW.17, CW. 18, CL.9, CD.9 dinyatakan bahwa pihak-pihak yang terlibat dalam pembuatan aturan dalam sentra difokuskan pada anak didik dalam bentuk kesepakatan. Hasil kesepakatan kemudian direalisasikan oleh guru dalam bentuk visual seperti tulisan-tulisan, gambar-gambar, simbol-simbol berupa aturan-aturan main ataupun aturan kegiatan dalam sentra yang dipajang pada dinding-dinding ruangan atau tempattempat strategis yang terlihat. Menurut Latih Zukhairini, Rita Zubaidah, Muhammad Affandi, " dalam membuat aturan hilangkan perkataan "jangan". (Latif, M, Zukhairini, Rita Zubaidah, Muhammad Affandi, 2013). Adapun contoh aturannya sebagai berikut: 1). Jangan bersuara keras dirubah menjadi Berbicara dengan Pelan, Ramah dan Sopan, 2). Jangan menginjak rumput dirubah menjadi "Sayangi dan Jagalah Aku" dan lain-lain.

\section{Waktu pembuatan Peraturan}

Waktu pembuatan peraturan kapan saja dan dimanapun anak didik berada dan walaupun peraturan dibuat di sekolah namun harapannya implementasi aturan dapat diterapkan atau diimplementasikan menjadi kebiasaan di rumah. (CW.19)

Berdasarkan pada CW.19 waktu pembuatan aturan biasanya di awal-awal masuk sekolah. Selain itu pembuatan dan penetapan aturan dapat dilakukan secara insidental pada saat ada event atau kegiatan. Dalam peraturan di masing-masing sentra biasanya sudah ada dan dapat dikembangkan sesuai dengan tema, kegiatan, situasi dan kondisi yang relavan.

\section{Evaluasi dalam Implementasi Model Sentra di TK Lab School STAI Bani Saleh}

Evaluasi dalam Model Sentra diTK Lab School STAI Bani Saleh adalah menggunakan beberapa bentuk dan jenis evaluasi antara lain anekdot, portofolio, observasi, performance maupun pemberian tugas sederhana dan dilaporkan kepada orang tua pada akhir semester ganjil dan akhir tahun atau semester genap yang merupakan laporan gabungan dari guru

Berdasarkan pada CW.19 dan CD.10 dapat dimaknai bahwa bentuk evaluasi menggunakan beberapa kriteria penilaian yang sesuai dengan kriteria penilaian pada lembaga pendidikan anak usia dini pada umumnya. Perbedaanya pada hasil evaluasi merupakan gabungan dari penilaian sentra yang berasal dari guru sentra dan dikalkulasi dengan guru kelas. Soejiono,"Dalam sistem Dalton dilakukan secara terpisah berupa laporan vak dan laporan kelas berupa Kartu Vak dan Kartu Kelas. Kartu Vak berupa Kartu Perorangan setiap murid dan ada kartu kelas yang berisi semua murid di dalam kelas. (Sujiono, 2009).

\section{KESIMPULAN}

TK Labschool STAI Bani Saleh telah mengimplementasikan model pembelajaran sentra, akan tetapi masih bersifat semi sentra. Hal ini terlihat adanya perbedaan dengan sistem Dalton yang dirancang oleh Dr, Helen Parkurst Amerika Serikat pada Laboratory Plan yang merupakan induk dari model pembelajaran sentra. 


\section{UCAPAN TERIMAKASIH}

Terima kasih disampaikan kepada semua pihak yang telah memberikan dukungan dan motivasi sehingga hasil penelitian ini dapat terpublikasi. Kepada lembaga STKIP Panca Sakti Bekasi, Labschool STAI Bani Saleh Bekasi dan editorial board Jurnal Obsesi : Jurnal Pendidikan Anak Usia Dini Universitas Pahlawan.

\section{DAFTAR PUSTAKA}

Aisyah, S. (2009). Perkembangan dan Konsep Dasar Perkembangan Anak Usia Dini . Jakarta: Universitas Terbuka.

Arifin. (2011). Konsep dan Model Pengembangan Kurikulum. Bandung: Remaja Rosdakarya.

Arikunto, S. (2013). Dalam Prosedur Penelitian Suatu Tindakan Pendekatan Praktek (hal. 231). Jakarta: Rieneka Cipta.

Caughlin, Pamela, Kristin A, Hensen, Dinah Heller, Roxana. (2000). Dalam Resourches Internasional Versi Bahasa Indonesia (hal. 167). Washington DC: CRI.

Depdikbud. (2014). Permendikbud Nomor 137 Tahun 2014. Jakarta: Departemen Pendidikan dan Kebudayaan Republik Indonesia.

Dimyati. (2013). Dalam Metodologi Penelitian Pendidikan dan Aplikasi pada Pendidikan Anak Usia Dini (hal. 92). Jakarta: Kencana Prenada Media Group.

Guza, A. (2005). Undang-Undang Sidiknas Dan Undang-Undang Guru Dan Dosen. Jakarta: Asa Mandiri.

Hapidin. (1999). Dalam Model-model Pendidikan Anak Usia Dini (hal. 2). Jakarta: Ghiyast Alfiani Press.

Hartati, S. (2005). Perkembangan Belajar Pada Anak Usia Dini. Jakarta: Departemen Pendidikan Nasional.

Heny Djoehani, M. O. (2005). Dalam Pendekatan Belajar Aktif di Taman Kanak-kanak (hal. 97). Jakarta: Departemen Pendidikan dan Kebudayaan .

Islamiah, F., Firdani, L., \& Asep, S. (2019). Konsep Pendidikan Hafidz Qur'an pada Anak Usia Dini. Jurnal Obsesi: Jurnal Pendidikan Anak Usia Dini. https://doi.org/ 10.31004/obsesi.v3i1.132

Latif, M, Zukhairini, Rita Zubaidah, Muhammad Affandi. (2013). Dalam Orientasi Baru Pendidikan Anak Usia Dini Teori dan Praktek (hal. 143-144). Jakarta: Kencana Prenada Group.

Majid, A. (2013). Dalam Strategi Pembelajaran (hal. 2013). Bandung: Remaja Rosda Karya.

Masitoh, Ocih Setiasih, Heny Djoehani. (2005). Dalam Pendidikan Belajar Aktif di Taman Kanakkanak (hal. 97). Jakarta: Deparetemen Pendidikan Nasional .

Nazir, M. (2005). Dalam Metodologi Penelitian (hal. 63). Bogor: Ghalia Indonesia.

Pamela Coghlin, d. (2000). Dalam Children Resourches International (hal. 167). Washington: CRI.

PAUD, Dirjen. (2006). Pedoman Penerapan Pendekatan Beyond Center and Crcle Time (BCCT). Jakarta: Departemen Pendidikan Nasional.

Sanjaya, W. (2006). Dalam Strategi Pembelajaran Berorientasi Standar Proses Pendidikan (hal. 127). Jakarta: Prenada Media Group.

Setyorini. (2010). Metode Penelitian dan Pengembangan . Jakarta: Kencana Pprenada Group.

Soejono, A. (1978). Aliran Baru Dalam Pendidikan Bagian ke-1. Bandung: CV Ilmu.

Sugiyanto, M. (1995). Dalam Bermain, Mainan dan Permainan (hal. 80). Jakarta: Departemen Pendidikan dan Kebudayaan Direktorat Pendidikan Tinggi Proyek Pendidikan Tenaga Guru.

Sugiyono. (2013). Dalam Metode Penelitian Pendidikan Pendekatan Kuantitatif, Kualitatif dan RE $D$ (hal. 203). Bandung: Alfabeta.

Sujiono, Y. N. (2009). Konsep dasar pendidikan anak usia dini. Jakarta: PT Indeks.

Suyanto. (2005). Konsep Dasar Pendidikan Anak Usia Dini. Jakarta : Departemen Pendidikan Nasional Direktorat Jenderal Pendidikan Tinggi. 
Syaodih, E. (2005). Bimbingan Konseling untuk Anak Usia Dini. Jakarta: Universitas Terbuka 2005.

Triyanto. (2015). Mendesain Model Pembelajaran Progresif dan Kontekstual. Jakarta: Kharisma Putra Utama.

Yunus. (2000). Teori-teori Belajar dan Aplikasi Pembelajaran Motorik Deskrisi dan Tinjauan Kritis. Bandung: Nusa Media. 